\title{
Local and Regional Programmes of Environmental Protection as the Instrument of Implementation of Environmental Policy
}

\author{
Dr. Dorota Strus
}

Siedlce University of Natural Sciences and Humanities, Poland

\begin{abstract}
The subject of the study is the analysis of programmes of environmental protection elaborated at the regional and local level. The paper indicates the conditions accompanying the shaping of programmes of environmental protection and the valid construction in the scope of their elaboration and implementation. The important issue to which attention was paid is the significance of programmes of environmental protection as a key element of the implementation of the national environmental policy.

Keywords: environmental protection, national environmental policy.

At the beginning it is worth to note that programming constitutes an important element of the management process. It comprises of designing the most desirable events and states from the point of view of the future situation, defined as goals of the environmental policy. Different entities take part in the process, starting from public institutions at the central level, through units of local self-government and entities included in the non-governmental sector [7, 110].

By way of introduction, it should be indicated that local programmes of environmental protection, including voivodship programmes, constitute an important instrument of the creation of the local public policy of environmental protection. The content of local programmes of environmental protection must correspond with tasks and goals resulting from the national environmental policy since they develop and refine it. It does not mean that they cannot contain different content being the consequence of local or regional conditions. Programmes of environmental protection specify principles, directions and priorities of projects undertaken in favour of environmental protection, which in practice is aimed at enabling effective and rational management of environment resources.
\end{abstract}


Dorota Strus. Local and regional programmes of environmental protection as the instrument of implementation of the environmental policy

All programmes of environmental protection are not local law acts, but only programmes of activity binding within administration. The result of it is that they do not cause any legal effect in the area of creation of rights and obligations in relation to entities from outside of administration. Analysed programmes are the expression of the principle included in Article 5 of the Constitution which makes the state the entity responsible for environmental protection and recognize the principle of sustainable development as one of the fundamental constitutional principles of the state. Taking into account the framework of this paper, the attention will be paid to the mechanism of programming in relation to local administration. The analysis of such issue requires rising the matter of conditions that accompanied the creation of this tool.

Sharing the view of Antoszewski and Ferens, it is worth to note that the process of gradual democratization of political system in the 1980's led to the increase of the possibility for different groups and non-governmental organizations to shape decisions. It resulted in the increase of activity of different policy-making bodies, also at the local level. As it was noted by the authors, the change of the political order that took place in the late 1980's made environmental protection being perceived in the category of political value which, on the one hand, was a serious argument against the communist authorities and, on the other, was the element of political agendas. [1, 7-9]

As practice has shown, circumstances mentioned above did not fundamentally affect the change of decision-making process in environmental protection by local authorities, i.e. national councils. The dominance of administration over the representative factor was still visible. For a long time local authorities did not participate in the process of programming and decision-making in environmental protection. As an example, it may be indicated that the first complex regulation from the scope of environmental protection in Poland i.e. the Act of January 31, 1980 on the protection and shaping of the environment indicated voivodes as the bodies responsible for the preparation of programmes of environmental protection.

At the beginning, the changes towards inclusion of commune bodies in the process of programming of environmental protection were connected with the amendments of the abovementioned Act made in 1997 and 1998 [9]. The extension of the personal scope in this area was connected with the process of further decentralisation of public administration in Poland which led the creation of successive levels of the state territorial division that are districts (poviats) and self-governing voivodships. The reform of administration has eliminated voievodes from programming processes. The institution of environmental protection programmes seems to be the basic tool of policy concerning the environment.

It is assumed that environmental programmes elaborated on the local level should provide details of the national environmental policy. In the legal state in force, on the basis of Article 17 (1) of the Act of April 27, 2001 Environmental Protection Law, environmental programmes should provide details of the national environmental 
Dorota Strus. Local and regional programmes of environmental protection as the instrument of implementation of the environmental policy

policy. It should be mentioned that their implementation corresponds with the provisions of Article 5 of the Constitution of the Republic of Poland which obliges the state, including units of local self-government, to provide environmental protection.

In the preliminary remarks of the paper the issue of conditions that has eventually influenced the role which can be fulfilled by local authorities has been raised. It is worth to emphasise that aside of political conditions, which were connected with the successive development of democracy and systematic changes, the key role was played by the conception of decentralisation of tasks in environmental protection in favour of local self-government which took place in 1990 and 1998. It should be noted that the abovementioned conception was in compliance with the Global Programme of Activity which was passed during the conference in 1992 in Rio de Janeiro which assumed the increase of participation of local authorities in the solution of environmental problems. The significant premise seemed also to be the elaboration of longterm programmes of environmental protection at the level of the European Community and later the European Union.

Returning to the essence, the attention should be paid to formal and legal aspects accompanying the elaboration of local programmes of environmental protection. On the basis of Article 17 and 18 of the Environmental Protection Law Act, programmes of environmental protection are elaborated every four years, but the activities that are included in them should concern next four years. Such a solution remains in compliance with the national environmental policy. The body that is empowered to draw up the draft of the programme is the executive body of the unit of local self-government: at the level of commune - the head of a commune (mayor or the president of a city), at the level of district (poviat) - the district (poviat) management board and at the level of voivodship - the voivodship management board. The provisions of Environmental Protection Law Act have introduced the requirement to give opinion about the draft by the executive body of a superior unit.

As it was emphasized by Bar M., the notion of the executive body of a superior unit should be understood as the body not in hierarchical subordination, but in territorial terms. It means that in case of voivodship programmes of environmental protection such a body is the minister in charge of environmental protection, while in relation district (poviat) programmes the opinion-giving body is the voivodship management board. In turn, drafts of commune programmes of environmental protection require the opinion of the executive body of a district (poviat). It should be added that the executive body of a local self-government unit is obliged to ensure the possibility of social participation in the proceeding concerning drawing up the environmental protection programme.

The procedure of proceeding with social participation is the object of a separate regulation, that is the Act of October 3, 2008 on Providing Information on the Environment and Environmental Protection, Public Participation in Environmental Protection and on Environmental Impact Assessment. In relation to a policy, a strategy, 
Dorota Strus. Local and regional programmes of environmental protection as the instrument of implementation of the environmental policy

a plan and a programme, the Act mentioned hereinbefore provides also the need to conduct strategic environmental assessment and to ensure the social participation in such proceeding. It should be noted that ensuring public participation in such proceeding is the result of the implementation of Article 7 of the Convention form Aarhus from 1998 [4].

It concerns social participation in relation to plans, programmes and guidelines relating to the environment. The body responsible for the conduct of procedure of social participation and strategic environmental assessment is the body that draws up the draft of the programme. After fulfilling the abovementioned requirements, programmes are passed in the form of a resolution by the legislative and control body of a commune, a district (poviat) and a voivodship i.e. the commune council, the district (poviat) council and the voivodship assembly in the mode indicated in the self-government acts. (According to Article 14 of the Act on commune self-government, Article 13 of the Act on district (poviat) self-government and Article 19 of the Act on voivodship self-government, resolutions are adopted by a simple majority of votes in the presence of at least half of the members in an open vote.) The execution of passed resolutions has been left to the executive body of a local self-government unit which is obliged to prepare, each two years, the reports from the implementation of environmental protection programmes and to present them to acceptance to a legislative body.

At this point the issue of the character of environmental protection programmes should be analysed. They do not have the status of local legal acts since they define a certain direction and priorities of activity in the scope of environmental protection. Therefore, the programmes of environmental protection do not have legally binding character which means that they do not entail direct legal effects in the field of rights and obligations of entities from outside of administration [2, 223]. They constitute an important instrument of activities undertaken to preserve and restore the equilibrium of nature. The structure of environmental protection programmes is the same as the structure which was provided by the Polish legislator in Article 14 (1) of the Environmental Protection Law Act which means that such programmes should comprise of ecological objectives and priorities, the type and the timetable of proecological activities, measures necessary to accomplish the goals including economic and legal mechanisms and financial resources. Such a structure of environmental protection programmes does not exclude the possibility to consider in their content the problems which occur in the area of the competence of a given self-government unit.

The guidelines of the Ministry of the Environment on the preparation of environmental protection programmes at the local and regional level are fundamental for a proper preparation of such programmes [10]. In voivodship programmes, according to the guidelines of the Ministry of the Environment, voivodship's own activities, coordinated activities and detailed guidelines for preparation of district (poviat) programmes should be included. Such a structure enables for a description of undertakings, deadlines 
Dorota Strus. Local and regional programmes of environmental protection as the instrument of implementation of the environmental policy

for achieving them and institutions responsible for their execution. The important matter is also the determination of costs and the funding sources including indication of sources of funds from the sources of enterprises and the external sources. In the course of works connected with their preparation all concerned institutions specialised in environmental protection and spatial planning appropriate for the scope of their activity, including entrepreneurs having impact on the environment and representatives of society, participate.

Voivodship programmes of environmental protection ought to be coordinated with sector programmes including first and foremost: tourism development programmes, programmes on water supply, air protection programmes, programmes on protection against noise, local spatial development plans, waste management plans. The determination of long-term goals corresponds with the national environmental policy and with the mission expressed in the voivodship development strategy. It is aimed particularly at the improvement of the quality of the environment and ecological security, increasing ecological awareness and the rational use of natural resources as well as the protection of natural heritage. They emphasise the necessity of sustainable use of energy, water and natural resources. Insurance of compatibility between voivodship environmental protection programmes and the mission resulting from the voivodship development strategy is achieved by the indication for the necessity to take actions directed towards activation of the market to act in favour of environmental protection in relation to increase eco-innovations in the process of the development of a region and support for the production of energy from renewable resources.

The specification of problem areas is done on the basis of data on the state of the environment provided in the report on the state of spatial development and the National Environmental Monitoring. In case of district (poviat) programmes, their structure, according the guidelines of the Ministry, is similar to voivodship programmes, but in case of detailed guidelines, they refer to the preparation of commune programmes which ought to be included into district (poviat) programmes. Only commune programmes of environmental protection comprise of only two parts: the description of its own tasks and coordinated tasks. It should be indicated that environmental protection programmes are elaborated on three levels of territorial division of the state, and they are different in content and the substantive scope which is connected with their territorial remit [3, 72].

At this point it is worth to note that both the national environmental policy and programmes of environmental protection are impact acts which stimulate the activities of entities that have an impact on the environment $[5,56]$. Separate requirements concerning the content of programmes can be established by the provisions of special acts. Attention should be paid to the determination of problem areas which consist of the strengthening of "green infrastructure", the limitation of emission, the reduction of absorption of water, materials and energy, the improvement of transport and the development of civic activity. 
Dorota Strus. Local and regional programmes of environmental protection as the instrument of implementation of the environmental policy

Returning to the provisions included in special regulations, one should indicate waste management plans prepared at the level of a commune, a district (poviat) and a voivodship which are included in the Act of April 27, 2001 on Waste. They are a part of proper environmental protection programmes and are drawn up on the terms and in the manner defined in the provisions on environmental protection.

The specificity of waste management plans consists of their content since they should include the indications concerning waste prevention, safe management of waste, the reduction of the amount of stockpiled waste. Plans in the scope of waste management should be drawn up in compliance with the national environmental policy. As it was noted by Radecki, taking into account the fact that the environmental policy is the most important conceptual document elaborated in the manner defined in the Environmental Protection Law Act, waste management plans should be in compliance with it. The contradiction of the plan with the national environmental policy justifies the repeal of the resolution on the plan as unlawful $[8,151]$.

As it was noted above, local programmes of environmental protection take into account requirements resulting from other specific regulations, among which the Nature Conservation Act should be mentioned. The content of Article 3 of the abovementioned act contains the obligation to involve the requirements of nature conservation in environmental protection programmes. It is worth to pay attention to the obligation included in Article 66 (1) of the Nature Conservation Act. It requires studies of directions and conditions of spatial management in communes and local spatial management plans to take into account the needs of the functioning and development of existing and planned botanical or zoological gardens.

The mentioned issue justifies drawing the attention to the essence and the significance of the so-called recovery programmes which are regulated by the provisions of Environmental Protection Law Act. Such programmes are drawn up in order to enforce the compliance with standards of the quality of the environment. Contrary to classic programmes of environmental protection, the legislator has given them the status of local legal acts. They are aimed at enforcing the compliance with infringed quality standards of the environment. Aside of the typical status of planning document, recovery programmes fulfill mainly regulatory function. Seeking for relationships between environmental protection programmes and recovery programmes is possible in a sense if one notices that the national environmental policy refers to the standards of the quality of the environment $[3,78]$.

The programme specifies the area that falls within the scope of its application, infringed standards of the quality of the environment along with the indication of the scope of the infringement, fundamental directions and the scope of activities necessary to restore the standards of the quality of the environment. They should be specified precisely in order to constitute the basis for elaboration the future material and financial schedule that is crucial for the effectiveness of activities. The content of the recovery programme comprises of the entities that use the environment to which 
obligations established in the programme are addressed and obligations of administrative bodies consisting of communicating the information about issued decisions which have an impact on the implementation of the programme [6, 326-327].

In conclusion it is worth to indicate that both the national environmental policy and environmental protection programmes analyzed in this part fall within the area of organisational activity of the state which essence boils down to the insurance of rational organization of activities on multiple levels of organizational structure of the state in order to achieve assumed goals to protect and improve the state of the environment. It seems that achievement of pro-ecological goals specified in planning acts is dependent on a number of conditions among which the political system of the state should be mentioned. It is important to create proper institutional framework, defined by the provisions of law, which shape oftentimes has proven the lack of rationality of the legislator.

\section{Vietējās un reǵionālās vides aizsardzības programmas kā vides politikas ieviešanas instruments}

\section{Kopsavilkums}

Raksta mērḳis ir analizēt vides aizsardzības programmas, kas izstrādātas reǵionālā un vietējā līmenī. Rakstā tiek uzsvērti nosacỉjumi, kas jāievēro, veidojot vides aizsardzības programmas un derīgas konstrukcijas to izstrādei un ieviešanai. Svarīgs jautājums, kam pievērsta uzmanība, ir vides aizsardzības programmu nozīmīgums kā galvenais elements valsts vides politikas īstenošanā.

Atslēgvārdi: vides aizsardzība, valsts vides politika.

\section{References}

1. Antoszewski A., Ferens A. Uwarunkowania procesu decyzyjnego w przedmiocie ochrony środowiska w strukturach władzy lokalnej. Warszawa: Wydawnictwo Szkoły Głównej Gospodarstwa Wiejskiego-Akademii Rolniczej w Warszawie, 1990.

2. Bar M. Dział III polityka ekologiczna oraz programy ochrony środowiska. In: Prawo ochrony środowiska: komentarz.

3. Barczak A. Zadania samorzqdu terytorialnego w zakresie ochrony środowiska. Warszawa: Dom wydawniczy ABC, 2006.

4. Convention on access to information, public participation in decision-making and access to justice in environmental matters drawn up on 25 June 1998 in Aarhus. Journal of Laws, 2003; 78(706).

5. Gruszecki K. Prawo ochrony środowiska: komentarz. Warszawa: Wydawnictwo Wolters Kluwer, 2007. 
Dorota Strus. Local and regional programmes of environmental protection as the instrument of implementation of the environmental policy

6. Pchałek M. Dział I Przepisy ogólne. In: Prawo ochrony środowiska: komentarz.

7. Poskrobko B., Poskrobko M. Zarzadzanie środowiskiem w Polsce.

8. Radecki W. Ustawa o odpadach: komentarz. Wydanie 2. Warszawa: Wydawnictwo Wolters Kluwer, 2008.

9. The Act of 29 August 1997 on the amendment of the Act on protection and development of the environment and amending some other acts (Journal of Laws, No 133, item 885) as well as the Act of 25 July 1998 on the amendment of some acts specifying the competences of public administration bodies in conjunction with the state's political reform (Journal of Laws, No 106, item 668).

10. The guidelines of the Ministry of the Environment on the preparation of the local and regional environmental protection programmes. Warszawa, 2002. 